\title{
A REPRESENTAÇÃO DO ASSENTAMENTO IRENO ALVES DOS SANTOS NO DISCURSO JORNALÍSTICO EM MEADOS DOS ANOS NOVENTA
}

\section{THE REPRESENTATION OF THE SETTLEMENT IRENO ALVES DOS SANTOS IN JOURNALISTIC DISCOURSE IN THE MID-NINETIES}

\author{
Cleverson Lucas dos Santos"
}

Andréa Mazurok Schactae"

\begin{abstract}
Resumo: Objetivou-se analisar os discursos veiculados pelo Jornal Correio do Povo do Paraná (antigo Correio da Cantuquiriguaçu), em 1996, sobre a ocupação da Fazenda Pinhal Ralo, da empresa Giacomet-Marodin, pelos agricultores ligados ao Movimento dos Trabalhadores Rurais Sem-Terra (MST). Utilizando-se os pressupostos teóricos da Análise do Discurso, elencou-se quais foram as condições de produção e de circulação linguísticas, os agentes envolvidos, a memória discursiva sobre a questão agrária brasileira, recuperando posicionamentos sobre a temática e a questão dos silêncios discursivos, que se mostram no Dito e Não-Dito jornalístico. Analisou-se, assim, como o discurso produzido representou tais sujeitos no que foi veiculado à época.
\end{abstract}

Palavras-chave: Análise do discurso. Jornalismo. Silêncio Discursivo.

\begin{abstract}
The objective was analyze the discourses conveyed by the newspaper Correio do Povo do Paraná (formerly Correio da Cantuquiriguaçu), in 1996, about the occupation of Pinhal Ralo farm, the company Giacomet-Marodin by farmers linked to the Movement of Landless Rural Workers (MST). Using the theoretical assumptions of Discourse Analysis, listed to what were the conditions of production and circulation linguistic, the parties involved, discursive memory on the agrarian issue, recovering positions on the issue and the question of discursive silences, which are shown in the Said and Not-Said journalistic. Analyzing as discourse produced represented such subjects which was published at the time.
\end{abstract}

Keywords: Discourse Analysis. Journalism. Discoursive Silence.

\footnotetext{
"Especialista em História, Arte e Cultura, UEPG, 2011. e-mail: cleverson_lucas@msn.com

"* Prof. Orientadora Dra. Andrea Mazurok Schactae. Dep. de História UEPG. e-mail: aschactae@gmail.com
} 


\section{INTRODUÇÃO}

Ao deparar diante de um texto jornalístico, com fatos e acontecimentos cotidianos, é necessário um pouco mais de atenção para com aquilo que é apresentado. A notícia pode ser tomada como expressão fidedigna da realidade, tal qual ela aconteceu. Ao contextualizá-la, porém, outros sentidos presentes podem emergir desse discurso.

Nessa perspectiva, considerando a noção de representação na construção do discurso sobre a realidade, é preciso perceber que todo relato é construção discursiva. A notícia é um relato construído de um acontecimento e que, em momento algum, substitui a própria realidade ou os elementos que nela estavam envolvidos. Em todo o discurso são percebidas vozes, às vezes infinitamente distantes, anônimas, quase impessoais, imperceptíveis, assim como as vozes próximas que ecoam simultaneamente no momento da fala (BAKHTIN apud MORAES, 2005, p.1).

Para compreender como se deu a construção dos discursos referentes a uma ocupação do Movimento dos Trabalhadores Rurais Sem-Terra (MST), utilizou-se os pressupostos teóricos da Análise do Discurso. As matérias produzidas por um jornal da região centro-oeste do Paraná, o Correio do Povo do Paraná, que na época denominava-se Correio da Cantuquiriguaçu, são construtoras de uma representação sobre o MST e sobre o assentamento Ireno Alves dos Santos. Pautando-se na teoria de Bourdieu e Orlandi, para a compreensão das condições de produção e de circulação linguísticas, é que se busca compreender quais são os sentidos produzidos destes discursos. Aquilo que foi dito, veiculado pela mídia na época, e o que não foi dito, mas que estava presente, significando com o dito.

Dessa forma, nessa análise, ao buscar o contexto de produção do discurso, as condições que acabaram moldando-o, direcionando-o, estará presente a noção de silêncio, também proposta por Orlandi e utilizada por Oliveira, Campista (2007); Braz (2009); Mello, (2008) exploram o sentido presente no silêncio. Ainda que não seja possível ver o silêncio - há somente pistas, só podemos vislumbrar seus traços -, por meio de fissuras, rupturas e falhas, podemos percebê-lo em todo e qualquer discurso. O silêncio é, assim, a "respiração" da significação e a linguagem é a passagem incessante das palavras ao silêncio e do silêncio às palavras. O silêncio é constitutivo da linguagem (ou viceversa) (MELLO, 2008, p. 2588) e, aqui, assume caráter de significação. Nas palavras de Orlandi, um homem em silêncio é um homem sem sentido (1992, p.37). Mais do que pensar em implícito, o não-dito, o que ficou por dizer, remete à memória discursiva.

Não existe ciência do discurso considerado em si mesmo e por si mesmo; as propriedades formais das obras desvelam seu sentido somente quando referidas às condições sociais de produção - e, por outro lado, às posições ocupadas por seus autores no campo da produção - e ao mercado para o qual foram produzidas. (BOURDIEU, 1996: 129) 
Além disso, Berger (1998) ressalta ainda que a linguagem compõe o que ela representa. Para com o discurso jornalístico isso significa dissolver a imparcialidade da notícia e do acontecido, e reconhecer a notícia como construção de um acontecimento pela linguagem. A imparcialidade também é questionada por Santos (2007), que destaca que todos os jornais se dizem imparciais e neutros, quando, na realidade, é impossível a imparcialidade, pois, ao produzir o relato, se produz o acontecimento pela linguagem.

Os dizeres não são, como dissemos, apenas mensagens a serem decodificadas. São efeitos de sentidos que são produzidos em condições determinadas e que estão de alguma forma presentes no modo como se diz [...]. São pistas que aprende a seguir para compreender os sentidos aí produzidos, pondo em relação o dizer com sua exterioridade, suas condições de produção. Esses sentidos têm a ver com o que é dito ali, mas também em outros lugares, assim como o que não é dito, e com o que poderia ser dito e não foi. Desse modo, as margens do dizer, do texto, também fazem parte dele. (ORLANDI, 1998, p.30).

Assim, continua a autora, o fato de que há um já-dito que sustenta a possibilidade mesma de todo dizer, é fundamental para se compreender o funcionamento do discurso, sua relação com os sujeitos e a ideologia, acionando aspectos discursivos presentes na memória. Esta, como recuperadora de sentidos já instituídos e cristalizados na sociedade, mantém determinadas leituras já constituídas. Dessa forma, a memória presentifica o discurso, mesmo ele não estando presente nos enunciados produzidos.

Pensando a mídia como prática discursiva, produto de linguagem e processo histórico, para poder apreender o seu funcionamento é necessário analisar a circulação dos enunciados, as posições de sujeito aí assinaladas, as materialidades que dão corpo aos sentidos e as articulações que esses enunciados estabelecem com a história e a memória. Trata-se, portanto, de procurar acompanhar trajetos históricos de sentidos materializados nas formas discursivas da mídia. (GREGOLIN, 2007, p.13)

Esta autora reforça que, na sociedade contemporânea, a mídia é o principal dispositivo discursivo por meio do qual é construída uma "história do presente" como um acontecimento que tensiona a memória e o esquecimento. É ela, em grande medida, que formata a historicidade que nos atravessa e nos constitui, modelando a identidade histórica que nos liga ao passado e ao presente (GREGOLIN, 2007, p.16).

Portanto, conforme afirma Bourdieu (1983), a compreensão do discurso está vinculada às relações de produção linguísticas nas quais ele é produzido. Onde o signo não tem existência (salvo abstrata, nos dicionários) fora de um modo de produção linguístico concreto, buscou-se perceber que o texto jornalístico, como produção discursiva, passa pelos mesmos critérios, com um aspecto a mais: além de ser tomado enquanto media, isso é, mediador destas condições discursivas, também ele próprio é uma pré-condição para produção do sentido 
discursivo. Com essa premissa, buscou-se desvelar as construções discursivas sobre a ocupação da Fazenda Pinhal Ralo, feitas pelo jornal, recompondo as condições de produção desse discurso. Procurou-se situar os diferentes agentes e instâncias envolvidos, que resultaram na produção textual final.

Considerando a memória discursiva constituída sobre a questão agrária, a pré-disposição para a constituição dos discursos, totalmente imersa em ideologias, dos diferentes grupos sociais, culturais, que constituem as classes sociais, e que determina as diferentes representações. Esta memória pode ser institucional e cristalizar percepções, e, ao mesmo tempo, se constituir em esquecimento que torna possível o diferente, a ruptura, o Outro. Aqui entra em ação a relação que a sociedade tem com a estrutura agrária, na posse da terra, na atuação dos movimentos sociais, na compreensão de reforma agrária. Relações essas que não se prendem ao linguístico, mas significam e constituem sentidos e até mesmo os sujeitos, inseridas no contexto em que foram produzidas.

A estrutura fundiária brasileira é uma construção que se insere como memória discursiva: a utilização do espaço, a compreensão dos lugares definidos na sociedade, proprietários e nãoproprietários, a maneira com que ocorreu a divisão ao longo do tempo, passam por vezes, como estruturas já cristalizadas e definidas, regrando também a construção dos discursos sobre o tema. Em um modelo que concentrou a posse das terras sob o domínio de uma pequena parcela da população, ocasionou a expulsão, durante toda a história brasileira, de um grande contingente de famílias do campo, para a formação dos imensos latifúndios.

Portanto, o discurso jornalístico contrapõe a empresa - a proprietária das terras - de um lado, e os agricultores semterras - os não-proprietários - de outro, dando a primazia a determinado grupo, relegando ao Outro, o espaço marginal, desqualificando-o em suas ações, em sua própria identidade.

A palavra é a arena onde se confrontam os valores sociais contraditórios; os conflitos da língua refletem os conflitos de classe no interior mesmo do sistema [...] A comunicação verbal, inseparável das outras formas de comunicação, implica conflitos, relações de dominação e de resistência, adaptação ou resistência à hierarquia, utilização da língua pela classe dominante para reforçar seu poder, etc." (BAKHTIN, 1997, p. 14)

Com isso, como ressalta Santos (2007), as vozes dos jornalistas interagem com as vozes das fontes propondo um sentido para os acontecimentos. Se, por um lado, os Sem-Terra indicam para as autoridades governamentais os latifúndios improdutivos, dialogando com o governo e a sociedade, através da imprensa, esta, por sua vez, enquanto expositora do real e, como tal, mediadora dos sujeitos envolvidos neste real, constrói seu discurso pela articulação das vozes dos vários sujeitos em conflito.

Ao considerar essa perspectiva, chega-se à ideologia que constitui os sujeitos e a própria formação dos sentidos (SANTOS, 2007, p. 96). 
Para compreender o discurso midiático, produzido no ano 1996, sobre a ocupação das terras da fazenda Pinhal Ralo de propriedade da empresa Giacomet-Marodin, em Rio Bonito do Iguaçu, no estado do Paraná, pelo MST, é necessário contextualizá-lo aos diferentes agentes envolvidos: trabalhadores do campo, empresa proprietária das terras, sociedade, poder público, bem como a empresa que produziu o jornal.

Cada estrutura componente desse discurso será analisada mais atentamente, permitindo perceber as teias que se ramificam a partir dos discursos. Contextualizado no tempo, insere-se tais formações no período de 1996. A análise percorreu, então, aspectos históricos, sociais e políticos.

O ano 1996 é parte de um período histórico no qual o país já experiencia a redemocratização, com governos eleitos pela participação popular, mesmo que estes não priorizassem as classes trabalhadoras. Grupos políticos ligados ao poder federal - Presidente Fernando Henrique Cardoso (1994-2002) - e ao poder estadual - Governador Jaime Lerner (1994-2002) - sinalizavam que não havia condições necessárias para a efetivação da reforma agrária almejada pelos agricultores. Mesmo diante de tantas contradições sociais, o apoio midiático para com o governo era irrestrito. Os movimentos sociais questionadores, por sua vez, eram combatidos duramente, em um jogo ideológico em que os indivíduos eram retratados quase sempre de maneira pejorativa.

Todo discurso, mas de modo ainda mais evidente o jornalístico, carrega uma tensão entre o texto e as condições de produção, ou seja, o sujeito jornalista convive em tensão com suas fontes, com a empresa jornalística e com os telespectadores, confirmando que as condições incluem a produção, a circulação e o reconhecimento, e que estas formatam e moldam o modo de dizer as coisas do mundo. Tais condições acham-se, portanto, não do lado de fora do discurso, mas, absolutamente inseridas nele. (SANTOS, 2007, p.100)

Assim, buscou-se responder qual é o papel do discurso midiático na representação das informações e da realidade. Perceber e desvelar quais são os interesses que permeavam as notícias, estruturas estas que conduziam para uma interpretação possível, já pré-estabelecida, em um recorte da realidade desconsiderando outras tantas vozes, que acabaram no silêncio discursivo. Partindo das formações discursivas, é possível perceber o não-dito. No confronto dos diferentes agentes no discurso midiático, perceber qual o jornal representa, a ser mantido, e quais são os discursos, juntamente com seus agentes que foram silenciados nessa construção.

\section{O CONTEXTO}

O texto jornalístico é uma representação ${ }^{1}$ dos fatos que diuturnamente são

\footnotetext{
${ }^{1}$ Representação: sf (representar+ção) 1 Ato ou efeito de representar. R. coletiva, Sociol: concepções e símbolos que resultam da interação social e adquirem um significado comum para os membros do grupo, suscitando-lhes reações emocionais semelhantes. O termo também é utilizado, sob a conceituação de Durkheim (Representação coletiva) e Moscovici (Representação social).
} 
transcritos nas páginas dos periódicos, o leitor se apropria de uma construção discursiva $^{2}$, que contém em si muito mais do que textualmente aparenta. Uma notícia é uma representação feita por um jornalista, ou considerando em um todo, da empresa de comunicação que veiculou o acontecido. Alguém que tenha participado ativamente, outro jornalista, bem como o próprio leitor recuperará diferentes formas de apreensão do discurso, outras representações.

Elencaram-se nessa análise os diferentes agentes envolvidos na ocupação da fazenda Pinhal Ralo, onde parte posteriormente se tornaria os assentamentos Ireno Alves dos Santos e Marcos Freire, para que, então de posse das notícias realizadas à época, fosse possível confrontar suas representações nas formações discursivas. Entre eles está o MST, agricultores, empresa proprietária das terras, movimento dos latifundiários, Estado, moradores dos municípios envolvidos, incluindo a empresa de comunicação responsável pelo jornal.

Assim, observa-se que as condições de produção discursiva são orientadas pelas relações sociais, históricas, culturais e econômicas que permeiam a produção textual. Além de crenças, valores e ideias presentes na sociedade, que atuam sobre ela, compondo a ideologia vigente; nesse caso, o ideário refere-se sobre estrutura agrária brasileira.

No trabalho de Bauer (1998, p.142), percebe-se que a estrutura agrária vigente, tal qual ela se mostra atualmente,

\footnotetext{
${ }^{2} \mathrm{O}$ discurso interpreta, numa correlação de forças sociais, a realidade. Desse modo, é possível pensar que, a apropriação do mundo é feita toda ela por meio de construções discursivas.
}

altamente concentrada, surge juntamente com o território e o modelo de exploração adotado por Portugal. Mesmo o processo de industrialização brasileiro não se fez por alterações fundiárias, mas preservando estruturas tradicionais de produção e dominação, perpetuando a exploração e a miséria no campo. As instituições econômicas, sociais e políticas que moldaram a questão agrária brasileira, cujos efeitos ainda perduram, foram forjadas no período da dependência colonial, iniciada com a "Descoberta" e estendendo-se até a Independência em 1822. Constitui uma espécie de tradição pensada "imutável", que deva reger as relações para com a posse da terra. Assume uma relação simbólica, que tende a justificar posses e dominação de uma classe em detrimento das outras. Sobre este aspecto, leva o autor a afirmar que:

O poder e influência dos grandes proprietários rurais têm sido historicamente muito grandes, impedindo-se sempre toda e qualquer mudança na estrutura agrária e no sistema de dominação, sufocandose as tentativas de rebelião ou obstruindo-se quaisquer medidas governamentais que tivessem a finalidade de restringir o poder dos latifundiários. Todas as tentativas de levar avante um projeto de redistribuição de terras, ou de diminuir-se o poder dos grandes proprietários, falharam. Desde o Brasil colônia, passando pelo Império e República, ciclo militar e período de redemocratização, pouco ou nada se fez para mudar as contradições oriundas da estrutura agrária. 
Incipientes iniciativas de reforma foram abortadas no nascedouro, como a de João Goulart no início dos anos 60, ou não saíram ou mal saíram do papel, como as de Castelo Branco e José Sarney. (BAUER, 1998, p.142-143)

Nas notícias, as posturas com relação à questão agrária e à posse da terra não aparecem, mas constituem sentidos. É nos entendimentos de uso e do valor atribuído ao espaço agrário que se constroem os discursos.

\subsection{OS TRABALHADORES E OS MOVIMENTOS SOCIAIS DO CAMPO}

Quem eram esses agricultores que "invadiram" a fazenda? De onde vêm, quais eram seus objetivos? São questões que caberiam muito bem na leitura da notícia, porém certas formações discursivas não deixam margem para o leitor estabelecer esse contraponto. Nesse caso, é preciso conhecer o histórico da atuação coletiva e associativa dos trabalhadores no campo. Cericato (2008) e Serra (2009) trazem este panorama.

Cericato (2008) reforça que, no Brasil, a questão agrária tem suas origens na forma como a terra foi sendo distribuída ao longo de nossa história. As sesmarias e a lei de terras de 1850 legitimaram a concentração fundiária ao impedir que colonos pobres e escravos tivessem acesso à propriedade da terra. Esse contexto faz que os "excedentes", os não-proprietários fossem se acumulando ao longo do tempo. Aumentando esse contingente, passaram a organizar-se para reivindicar seus direitos de trabalhar a terra. Ainda durante o regime militar, grandes grupos empresariais beneficiaram-se com a apropriação de imensas áreas de terra, aumentando o número e a extensão de latifúndios por meio de incentivos governamentais. Segundo Stédile e Fernandes (1999, p. 62), nas décadas 1960 e 1970 a política agrícola em execução reafirma a concentração da terra por incentivos à produção para a exploração introduzindo novas tecnologias que exigem alto investimento de capital, processo que resulta na expropriação de pequenos produtores de suas terras; parte destes seguem para a periferia das grandes cidades e muitos passariam a integrar o MST na década 1980.

$\mathrm{Na}$ apresentação do site do MST, ressalta-se que durante a década de 1980, o Brasil vivenciava um momento onde se lutava pela abertura política, em busca do fim da ditadura militar. Nesse contexto, é que ocorre entre os dias 20 e 22 de janeiro de 1984, o $1^{\circ}$ Encontro Nacional dos Sem Terra, em Cascavel, no Paraná. Esta reunião é o ponto de partida para a construção do MST - Movimento dos Trabalhadores Rurais Sem-Terra ${ }^{3}$. No ano seguinte, em 1985, ainda sob o clima que marcou a campanha pela redemocratização "Diretas Já", o MST realiza seu primeiro Congresso Nacional, em Curitiba, Paraná.

\footnotetext{
${ }^{3} \mathrm{~A}$ atividade reuniu 80 trabalhadores rurais que ajudaram a organizar ocupações de terra em 12 estados: Rio Grande do Sul, Santa Catarina, Paraná, São Paulo, Mato Grosso do Sul, Espírito Santo, Bahia, Pará, Goiás, Rondônia, Acre e Roraima, além de representantes da Abra (Associação Brasileira de Reforma Agrária), da CUT (Central Única dos Trabalhadores), do Cimi (Conselho Indigenista Missionário) e da Pastoral Operária de São Paulo.
} 
Neste ano, o governo de José Sarney aprovou o Plano Nacional de Reforma Agrária (PNRA), que tinha por objetivo aplicar o Estatuto da Terra e assentar 1,4 milhão de famílias, mas que acabou em cinco anos, assentando apenas 90 mil famílias.

$\mathrm{Na}$ região de Rio Bonito do Iguaçu, onde estão localizados os assentamentos em questão, é o mesmo território em que em 1979 ocorreu a construção de uma das principais usinas hidrelétricas do estado do Paraná, a Usina de Salto Santiago, que deixou desalojados inúmeros agricultores, que ficaram sem suas terras devido à formação do lago da barragem. Serra (2009, p. 12) destaca este fato é como um dos germens que levou à organização campesina no estado do Paraná. Nesse período não havia um trabalho coletivo para resistir e pressionar a empresa por indenizações justas pelas desapropriações:

O primeiro empurrão neste sentido foi desencadeado pela construção das barragens da Usina de Salto Santiago, no Rio Iguaçu, região Sudoeste do Estado, que ao ser concluída, em 1979, inundou grandes extensões de áreas agrícolas nos municípios de Laranjeiras do Sul, Chopinzinho, Mangueirinha e Coronel Vivida e expulsou pelo menos 170 famílias de produtores rurais. $\mathrm{Na}$ época, os movimentos não estavam ainda organizados no Paraná, o que equivale a dizer que não havia pressão social por parte dos desabrigados, no sentido de negociar valores justos para indenização das terras inundadas. Aproveitandose disso a Eletrosul (empresa pública), responsável pelas obras da hidrelétrica, jogou para baixo o valor das indenizações. (SERRA, 2009, p. 2)
Com isso, relata o autor, foi na derrota desses agricultores do caso Santiago que ficou o alerta. Acrescenta que a história do baixo valor das indenizações só não se repetiu na construção de outra usina, a Hidrelétrica de Itaipu, porque os agricultores estavam cientes do que havia acontecido em Salto Santiago e resolveram se organizar. Pois o valor das indenizações das terras, anunciado pela Itaipu Binacional, responsável pela construção e exploração da usina, foi igualmente considerado aquém dos preços de mercado. A grande maioria era de pequenos proprietários, que não aceitaram tal situação e, com o apoio das igrejas Católica e Luterana, por meio da CPT-Comissão Pastoral da Terra, decidiram estabelecer uma luta organizada para exigir indenizações mais justas.

O MST unificou os diversos movimentos campesinos existentes sob a bandeira da organização e do trabalho coletivo. Foi a partir deste princípio que, no caso de Rio Bonito do Iguaçu, além das famílias da região envolvida, também entraram outras, advindas principalmente da região oeste do estado, de Foz do Iguaçu e imediações.

Foi assim que, em 1996, reuniram-se em torno de 3000 famílias, divididas em dois acampamentos, às margens da BR158, que corta o município de Rio Bonito do Iguaçu, ficando situados nas duas extremidades desse território, próximos à Saudade do Iguaçu e Laranjeiras do Sul.

\subsection{A empresa Giacomet-Marodin e OS LATIFUNDIÁRIOS}

Com a reabertura política, as diversas classes sociais presentes voltaram a organizar-se em grupos e associações em torno de 
objetivos comuns, o que fez que, além dos sindicatos de trabalhadores que voltaram à ativa, os proprietários fortalecessem suas bases, por instituições semelhantes. A UDR (União Democrática Ruralista) é um exemplo disso. Surge por volta de 1985, representando os interesses dos proprietários de terras.

Conforme o MST, tal entidade aproveitou-se da Assembleia Constituinte, em que os ruralistas se organizaram também, atuando em três frentes: um braço armado, utilizando-se de violência no campo, à composição e financiamento de uma bancada ruralista no parlamento e tendo também a mídia como aliada. (MST, 1999)

Lembrando que o modelo dos incentivos agrícolas durante o Regime Militar primava pela modernização do latifúndio, incluindo o país no comércio mundial pela produção de materiais primários: neste caso, do plantio de soja. O crédito rural nesse período favorecia a constituição e a manutenção dos latifúndios, pois, quanto maior a propriedade, mais crédito estaria disponível, podendo comprar ainda mais terras, diminuindo consideravelmente o número de pequenas e médias propriedades durante esse período. Essa prática forçou também que um grande número de trabalhadores do campo ficasse sem suas terras, por grilagens e apropriações praticadas pelos grandes proprietários, ao redor de sua propriedade.

Conforme o site institucional da empresa Araupel, em 1972, dois grupos tradicionais com atuação desde a década 1910 no ramo da madeira, a Madeireira Giacomet S.A. e a Marodin S.A. Exportação se unem e constituem no Rio Grande do Sul a Giacomet-Marodin Indústria de Madeiras S.A., adquirindo 100 mil ha de terras e florestas no sudoeste do Paraná4.

$\mathrm{O}$ imenso latifúndio se formou por brechas legais permitidas pela conivência, e até mesmo incentivo, das autoridades competentes. Uma extensa faixa contínua de terras que abrangia cinco municípios: Rio Bonito do Iguaçu, Nova Laranjeiras, Espigão Alto do Iguaçu, Três Barras do Paraná e Quedas do Iguaçu sob os domínios de um único grupo empresarial.

A história agrária paranaense é marcada pela ação de empresas como a madeireira Giacomet-Marodin e outras, que também eram colonizadoras. Adquiriam junto ao Estado extensos territórios para exploração da madeira e também dos territórios que passariam a receber povoamento. Algumas regióes já contavam com moradores, os posseiros, que não detinham a posse documental da terra e eram expulsos violentamente das terras ${ }^{5}$.

Ainda hoje, no Brasil, devido à extensão do território e aos espaços urbanos ficarem concentrados mais próximos às capitais e algumas poucas cidades, a grande maioria dos outros municípios é essencialmente agrária. Isso faz que a produção agrícola seja, neste caso, determinante para o sucesso destes locais. Com isso, percebe-se que, a

\footnotetext{
${ }^{4}$ A empresa altera sua razão social em 1997, justamente pelo conflito com os trabalhadores rurais. A situação que marcou a alteração foi o assassinato de dois integrantes do acampamento em seu território: Vanderlei das Neves, 16 anos e de José Alves dos Santos, 34 anos.

${ }^{5}$ Relatos orais dão conta de que esse mesmo território já foi palco de ocupações na década 1980, após a expropriação pela Usina de Salto Santiago. Porém como eram poucas famílias, essas foram violentamente expulsas. Não há registros documentais para tal fato.
} 
partir da estrutura agrícola, toda a composição histórica, social, política e econômica gira em torno dos latifundiários. Surgem empresas ligadas ao ramo de atividades das propriedades, movimentando a economia local. É quase uma constante também que grandes proprietários de terras integrem os postos políticos. Isso faz que se mantenha o Estado atrelado a uma política agrária favorável a este modelo agrícola.

\subsection{O Estado - Poder Público}

Importante incluir nesse levantamento o Estado na condição de peça central nas disputas entre proprietários e não-proprietários de terra. Inicialmente, supõe-se que a estrutura do poder público deva assegurar direitos iguais a todos os cidadãos, permitindo-lhes reivindicar aquilo que julgam necessário a sua sobrevivência, como também proporcionar condições vitais para todos, como moradia, trabalho, saúde, educação dentre outras.

Mas há que se considerar que tais representantes são advindos da própria sociedade, em que basicamente os políticos são os mesmos proprietários das terras, e tem na área agrícola sua principal fonte de renda. A força que adquirem os proprietários, detentores da estrutura agrícola, é consideravelmente maior do que a dos trabalhadores que não possuem pouca representatividade.

Importante destacar as instâncias governamentais da época: no município de Rio Bonito do Iguaçu, o prefeito da época - e atual -, um tradicional produtor agropecuarista da região, Sezar Augusto Bovino
(1993-1996) ; o estado do Paraná era governado por Jaime Lerner (1995-2002) e o país nesse momento contava com o presidente Fernando Henrique Cardoso (1995-2002). Para o contexto agrário brasileiro, o período da ação realizada pelos agricultores sem-terra era bastante adverso, de políticas de abertura a globalização dos mercados, de teorias neo-liberais em que se priorizava o livre comércio, estado mínimo e as políticas sociais regidas pelo mercado.

1.4 O jornal Correio do Povo do PaRANÁ dE LARANJEIRAS do Sul

Por fim, mas centralizando a análise, insere-se o Jornal Correio do Povo do Paraná de Laranjeiras do Sul. Uma empresa que, como as demais do ramo da comunicação, tem por objetivo trabalhar com a informação, a tradução dos fatos que acontecem. Isso faz que, sob a égide do media, almeje ser um espaço de mediação das diferentes vozes.

Mas não se pode esquecer que um jornal é produto de uma empresa. A notícia é a manufatura do jornalista, que a produz conforme objetivos definidos, inserindo-a em um mercado próprio, que contém anunciantes, assinantes e consumidores.

Geralmente, os jornais do interior e de pequeno e médio porte estruturam-se em anunciantes, publicação legal e matérias "pagas". Um jornal compõe-se das matérias que veicula,

\footnotetext{
${ }^{6}$ Rio Bonito do Iguaçu, torna-se município independente de Laranjeiras do Sul, em 19 de março de 1992. Sezar Augusto Bovino é vereador de Laranjeiras do Sul à época, representando o então distrito. Na primeira eleição é eleito prefeito. Seu vice, Leonel Schimitt, elege-se na sequência, (1997-2000); Bovino, volta então ao poder, (2001-2004) e (2009-2012).
} 
mas também das empresas que anunciam nele. Os anunciantes são em sua grande maioria empresas da própria região, que restringem a linha editorial a interesses mais próximos deste público. Na publicação legal, a relação é com o poder público. As prefeituras da região necessitam, por lei, publicar seus atos oficiais em diário oficial. Isso é feito por periódicos regionais, em que se gera uma relação política.

$\mathrm{Na}$ época, vários municípios que compõem a microrregião denominada Cantuquiriguaçu, utilizavam-se deste expediente para as publicações oficiais (dentre elas, as prefeituras de Laranjeiras do Sul, Nova Laranjeiras, Virmond, Guaraniaçu, Cantagalo, e em específico, Rio Bonito do Iguaçu). Mesmo por meio de licitações, a manutenção da concessão desse serviço passa por uma textualidade favorável às administrações. Outra prática são as matérias pagas, que articulam notícia com conteúdo publicitário. Aparentemente são como qualquer outra notícia, mas traz em si texto vinculado a uma empresa ou produto que está sendo inserido na região.

Os responsáveis pelo jornal, tanto pela redação quanto pela área administrativa, eram Ademir Fagundes, em Laranjeiras do Sul, e Jair Pereira Gomes, em Guaraniaçu. Posteriormente, Ademir Fagundes e sua esposa Joice Fabrício detêm todo o controle do periódico. Os proprietários mantinham, conservando suas posições ao longo do tempo, estreita relação com grupos políticos regionais.

A notícia

Toma proporções os movimentos dos sem terras e as invasões, gerando insegurança civil em todo o país e a nossa região também se vê envolta a invasão de uma área que é considerada pelo Movimento dos Trabalhadores Rurais Sem Terras, como o maior latifúndio do Paraná. Na Fazenda Giacometi, parte localizada no Município de Rio Bonito do Iguaçu (abrangendo $5 \mathrm{mu}$ nicípios e totalizando 83 mil hectares), foi parcialmente invadida por cerca de 3 mil famílias cadastradas pelo MST perfazendo cerca de dez mil pessoas e o caso agora corre na justiça.

Jornal da Cantuquiriguaçu - ano IV $n^{\circ}$. 159 de 25 de Abril a 8 de Maio de 1996.

Para a maioria da população, a construção discursiva midiática corresponde fidedignamente ao que de fato aconteceu. No apresentado percebe-se que a compreensão de que um grande contingente de pessoas estaria imbuído da intenção de fazer uso de um território, leva à interpretação de que haverá momentos de violência. É uma leitura da realidade. Nesse sentido, a "insegurança civil em todo o país", conforme afirmação contida no jornal, causada pelo MST, reforça um posicionamento esperado de uma parcela da sociedade e do próprio jornal.

Não há enunciação neutra. Abramo (1988) já afirmava que a maior parte do material que a imprensa oferece ao público tem algum tipo de relação com a realidade. Apresenta a realidade mas também posiciona-se diante dela. Em nome da própria estrutura empresarial que a sustenta, nos proprietários, na equipe de trabalho, linha editorial, bem como dos fatores externos a empresa de comunicação, assinantes, anunciantes, relações com o poder político e econômico local, regional e 
nacional. Tais componentes não aparecem no noticiário, mas são condicionantes dele. A realidade apresentada:

É uma realidade artificial, não-real, irreal, criada e desenvolvida pela imprensa e apresentada no lugar da realidade real. A relação entre a imprensa e a realidade é parecida com aquela entre um espelho deformado e um objeto que ele aparentemente reflete: a imagem do espelho tem algo a ver com o objeto, mas não só não é o objeto como também não é a sua imagem; é a imagem de outro objeto que não corresponde ao objeto real. (ABRAMO, p. 23-24, 1988-grifos do autor)

Mesmo a realidade que se experiencia é uma leitura que se faz pelo filtro das interrelações humanas: o contexto sociocultural, político, econômico, traduzirá cada fato tendendo para as expectativas e necessidades de cada indivíduo. Visto que o discurso é um lugar de investimentos sociais, históricos, ideológicos, psíquicos, por meiode sujeitos interagindo em situações concretas (CARDOSO apud BRAZ, 2009, p. 6). Assim, não há media, mas a constituição de mais um agente nas condições de produção do discurso; com o diferencial de que é um fator que pode ou não agregar outros agentes.

O movimento é pacífico e nenhum problema, por menor que seja, foi registrado pela Polícia Militar de Laranjeiras do Sulelíderes dosacampados garantem que tudo o que querem, é mostrar ao governo federal e ao estadual, que no Paraná existem sem terras. [...] Líderes garantem que vão esperar os sessenta dias prometidos para solução e ver as promessas de Fernando Henrique Cardoso e Jaime Lerner serem cumpridas, não estando previstas invasões em áreas próximas. (Jornal Correio da Cantuquiriguaçu, Ano IV, n. $\left.{ }^{\circ} 158,1996\right)$

Mostra-se que um movimento popular inicialmente é caso de polícia. Há, assim, um grupo de pessoas reunidas, inominadas, partícipes de um movimento, que possivelmente juntas poderão gerar algum tipo de distúrbio social. Os líderes permanecem no anonimato, marcado também pelo uso do discurso indireto que lhes nega a expressão objetiva dentro do texto. Não há lugar para os acampados no texto jornalístico. O discurso indireto é uma releitura do expresso pela pessoa, relegando ao silêncio às demais expressões de grupo.

Documento oficial expedido pelo Movimento dos Trabalhadores Rurais Sem Terra, explica que a invasão da Fazenda Giacomet se deu por ser o maior latifúndio existente no Estado do Paraná, formado por $83 \mathrm{mil}$ hectares de área e a mesma está sendo mal utilizada. A terra abrange cinco municípios e a empresa madeireira se dedica basicamente a extração de madeira e que na década de 80 , 0 Instituto de Terras e Cartografia do Paraná constatou que a empresa não possuía nenhuma documentação sobre 2 mil e 400 hectares. [...] Outro fato alertado pelo MST, é de que a família Giacomet encaminhou a justiça pedido de reintegração de 49.881, 97 hectares e que esta é a área que a empresa possui documentação e representam cerca de $60 \%$ do total 
existente. Esta é a maior invasão já realizada desde 1950 e os sem terras adiantam que não vão sair nem com força policial. (Jornal Correio da Cantuquiriguaçu, Ano, IV, nº.159, 1996)

Uma propriedade com dados imprecisos sobre sua real dimensão é questionável. Duas informações se destacam: 2400 hectares indicados no documento do MST sobre estudodo Instituto de Terras e Cartografia do Paraná que não possuem documentação e o pedido de reintegração de posse de aproximadamente 50 mil hectares e não da totalidade da área. Contraposto a isso, novamente apresentase o aspecto da violência e da irregularidade do movimento, em uma ação de invadir um espaço que não lhe pertence.

Quanto à área agricultável, documento da Marodim diz que ali se faz a utilização racional e múltipla da propriedade, com áreas modernas de agricultura mecanizada com os maiores índices de produtividade da região.

Ouvindo prefeitos da região e que estão com a fazenda em suas áreas, defendem que a Giacomet Marodim mantém as áreas em utilização, tirando notas fiscais de comercialização e gerando impostos para os municípios. Um dos maiores defensores é o prefeito Sezar Bovino de Rio Bonito que informa "a área invadida não é improdutiva, é uma das fazendas mais bem organizadas do Estado, com cultivo de diversos produtos $\mathrm{e}$ parte da área é reservada ao reflorestamento, onde cada árvore derrubada é reposta”. Bovino se manifestou satisfeito por a invasão ter ocorrida de forma pacífica e que torce para que assim continue. "Não incentivei o movimento nas invasões ao ajudar dando lonas, estamos dando a ajuda que o município pode fazer pensando nas famílias, filhos e na saúde deles", disse Bovino que vê a situação precária de vida em que estão os sem terra. (Jornal Correio da Cantuquiriguaçu, Ano IV, $n^{\circ}$. 159, 1996).

Neste trecho, dando continuidade à cobertura sobre a ocupação da fazenda Pinhal Ralo, o jornal aborda a questão da empresa, ressaltando que naquele espaço se faz uma agricultura moderna e mecanizada, termos contraposto a imagem de atraso relegada aos manifestantes. É interessante também pensar que em uma região com pequenas propriedades, sem capital para realizar investimentos pesados em tecnologia, nem em maquinários, certamente se destacaria essa propriedade.

A figura do poder público local aparece e em diversos momentos seguintes, em matérias que irão se seguir nos desdobramentos até o início da formação do assentamento, como um mediador. Inicialmente, faz uma defesa inconteste da empresa, nas palavras de Bovino, prefeito do município de Rio Bonito do Iguaçu na época, "uma das fazendas mais bem organizadas do Estado", e vai além, aparentando ter uma ligação muito próxima com a empresa, pois afirma que ali existe "cultivo de diversos produtos e parte da área é reservada ao reflorestamento, onde cada árvore derrubada é reposta”. Por outro lado, aparece fazendo o contraponto 
na assistência social às famílias, que estava sensível à situação precária das famílias.

Há uma clara motivação política presente em trazer a figura do prefeito para o centro de uma ação que se dá entre o Movimento Sem Terra e a empresa privada Giacomet-Marodim. Nas reportagens já apresentadas, demonstra-se que os governos federal, de Fernando Henrique Cardoso, e estadual, de Jaime Lerner, ambos de linha neoliberal, não estavam preocupados com a questão.

Assim, as figuras políticas regionais aparecem utilizando-se do fato, para obterem notoriedade à custa do acontecimento. Sezar Bovino também é um grande agropecuarista da região envolvida. Isso torna seu discurso sobre a preocupação com os ocupantes da propriedade bastante contraditório. $O$ jornal também traz o posicionamento do deputado Nereu Moura (PMDB), que detinha o mando político da região. Isso faz que veículos de comunicação atrelem-se as suas opiniões e destaquem suas ações, obtendo benefícios e verbas de publicidade e de publicação institucional. Nereu é agropecuarista, com propriedades na região sudoeste do estado; compunha na época a Comissão de Terras, Imigração e Colonização da Assembleia Legislativa. Por esse retrospecto, espera-se a defesa dos interesses do agronegócio, dos médios e grandes proprietários de terras. Na edição n. 159, de maio de 1996, o deputado Nereu Moura (PMDB) é colocado como um possível solucionador da questão apresentada.

Com uma periodicidade quinzenal, o jornal traduziu os fatos de uma maneira ainda mais fragmentada, deixando de lado fatos e ocorrências corriqueiras de lado. Sobre esse aspecto, Abramo (1988, p.25) ressalta isso como um padrão de manipulação feito pela imprensa. É o padrão da ocultação, "que se refere à ausência e à presença dos fatos reais na produção da imprensa".

Ora, o mundo real não se divide em fatos jornalísticos e não-jornalísticos, pela primária razão de que as características jornalísticas, quaisquer que elas sejam, não residem no objeto da observação, e sim no sujeito observador e na relação que este estabelece com aquele. O "jornalístico" não é uma característica intrínseca do real em si, mas da relação que o jornalista, ou melhor, o órgão de jornalismo, a imprensa, decide estabelecer com a realidade" (ABRAMO, 1988, p.26).

Outro registro sobre o acampamento só irá aparecer três meses mais tarde, marcado pela tragicidade. A manchete da edição 164 , de 25 de junho a 10 de julho de 1996, "Nove crianças já morreram no acampamento", é impactante. A reportagem traz que "a coordenação do movimento informou que até agora, 11 crianças já morreram e que falta mantimentos, medicamentos e agora vão ter dificuldades com agasalhos devido a chegada do inverno", contraposto às palavras do secretário de saúde do município que "é do seu conhecimento, a morte de nove crianças até agora por desnutrição e infecção pulmonar, devido às péssimas condições do local, mas que algumas já vieram neste estado". Há um jogo discursivo que irá questionar quem tem razão sobre a questão. Ainda sob o mote da violência e da 
criminalização, avançando-se em 1996, no mês de outubro, a manchete é "Sem-terras desrespeitam a justiça”. A reportagem traz a seguinte redação:

Não cumprindo determinação judicial de se manterem apenas na área ocupada, cerca de 100 famílias dos acampados na Fazenda Pinhal Ralo se rebelaram ao comando do atual grupo formado por 1900 famílias e resolveram acampar em outra parte, cerca de quinze quilômetros da mesma fazenda, gerando novo impasse no processo de assentamento negociado entre Giacomet e Governo, podendo se interromper e até exigir ação de despejo imediata, sem qualquer outro tramite legal (...).

Os invasores abandonaram a área permitida e tomaram área proibida e a ação de despejo deve acontecer automaticamente caso os mesmos não retornem ao acampamento. (Jornal Correio da Cantuquiriguaçu, ano IV, n. 172, 1996)

Quando ocorrem dois assassinatos no acampamento, situação que colocou em xeque a empresa e os agricultores, o governo federal assina o Decreto Presidencial n. 5085/1997, autorizando a desapropriação de parte da fazenda para se realizar o assentamento. Na edição 177, já em janeiro de 1997, dá-se voz apenas ao chefe da segurança, que valida o discurso da empresa ao afirmar que o conflito ocorreu entre caçadores da região e o grupo sem-terra.

\section{CONSIDERAÇÕES FINAIS}

A realidade apresentada é um recorte espaço-temporal, em que os indivíduos fazem o uso da palavra ou do silêncio. A palavra nãoéum direito adquirido nos meios de comunicação, é, antes de tudo, concessão de quem produz a textualidade. O silêncio também é assim um aspecto significante: ou o indivíduo não se pronunciou, sua fala não era importante, ou não havia interesse em publicá-la. As pessoas dialogam não só com palavras, mas também com silêncios. Quando falamos, sabemos que o silêncio é constitutivo da comunicação e que entre as réplicas, as frases, as palavras e as sílabas há silêncios. O silêncio é uma outra forma de expressão. O silêncio fala. (MELLO, 2008, p. 2590).

A compreensão do discurso jornalístico requer interagir com as diferentes condições de produção e de circulação discursivas, além de perceber qual é a ideologia vigente nessa conjuntura. Desde a época colonial, o modo de pensar e a cultura interiorana foram sempre expressão da ideologia das classes dominantes. (BAUER, 1998, p. 158). Tal aspecto está presente na atuação jornalística realizada, visto que não há questionamento desta estrutura.

Desse levantamento, é possível destacar a opção por um discurso favorável às elites agrárias, à defesa do grande latifúndio, independentemente se ele cumpra, de fato, sua função social, nem se questiona $o$ processo em que ele foi formado. Um discurso, vinculado ao poder político regional, de utilização da comunicação para manutenção das figuras públicas vigentes, que mantém estreita relação entre o Estado e a posse da terra. Nesse mesmo discurso, silenciase os trabalhadores do campo, deixando para eles o recorte da violência e desordem social. Nas representações mostradas, os próprios sujeitos 
são deslegitimados ao contestar a estrutura agrária vigente, sob a égide de um discurso único, que pudesse traduzir a realidade.

\section{REFERÊNCIAS}

AYOUB, H. A. Mídia e movimentos sociais: a satanização do MST na Folha de S. Paulo. Estudos em Jornalismo e Mídia v.IV, n. $1-1^{\circ}$ semestre de 2007. Disponível em < http://www. periodicos.ufsc.br/index.php/jornalismo/ article/view/1888> Acesso em: 27 Fev. 2011.

BAUER, G. G. T. Sobre as Origens da Questão Agrária Brasileira. Revista de História Regional, Ponta Grossa, 3, set. 2007. Disponível em: <http://www.revistas.uepg.br/index.php?j ournal $=$ rhr\&page $=$ article\&op $=$ view\&path $\% 5 B$ $\% 5 \mathrm{D}=82 \&$ path\%5B\%5 D=52.> Acesso em: $27 \mathrm{Fev}$. 2011.

BERGER, C. A Reestruturação da Política em Tempos Midiáticos. Intexto, Porto Alegre: UFRGS, v. 1, n. 1, p. 1-11, janeiro/junho 1997. Disponível em: <http://seer.ufrgs.br/index. php/intexto/article/view/3298/3944>. Acesso em 28 Set 2010.

BOURDIEU, P. A economia das trocas linguísticas. $O$ que falar quer dizer. São Paulo, EdUsp. 2.ed. 2008.

BRAZ, M. R. R. M. da C. A Difusão da Informação: Comunicação, Linguagem e Discurso. Revista ComUnigranrio. v. $1, \mathrm{n}$. 1, 2009. Disponível em <http://publicacoes. unigranrio.edu.br/index.php/comunigranrio/ article/viewFile/699/554> Acesso em: 11 Mar. 2011.

CABECINHAS, R. Representações sociais, relações intergrupais e cognição social. 2004. Universidade do Minho - Portugal. Disponível em: <http://sites.ffclrp.usp.br/paideia/artigos/28/02.htm> Acesso em: 07 Mar. 2011.
CERICATO, K.A.S. Os princípios organizativos e a proposta pedagógica do MST: contradições de sua materialização na Escola Estadual Iraci Salete Strozak. Dissertação de Mestrado. UEL, Londrina, 2008.

FERNANDES, B. M.; STEDILE, J. P. Brava gente: a trajetória do MST e a luta pela terra no Brasil. São Paulo: Fundação Perseu Abramo, 1999.

Jornal Correio do Povo do Paraná. Edições 151-, 1996.

MELLO, R. de. Osilêncio faz sentido. Artigo 287. In. MAGALHÃES, J. S. de. TRAVAGLIA, L. C. Universidade Federal de Uberlândia. Coletânea de trabalhos apresentados no XI Simpósio Nacional de Letras e Linguística e I Simpósio Internacional de Letras e Linguística, realizado em Uberlândia de 22 a 24 de novembro de 2006. Disponível em <http://www.filologia.org.br/ ileel/artigos/artigo_146.pdf> Acesso em: 28 Fev. 2011.

MORAES, N. A. Discurso, análise de discurso e memória. Disponível em: <http://www. nilsonmoraes.pro.br/nm/NM-1pdf.pdf> Acesso em: 27 Fev. 2011.

PRESIDÊNCIA DA REPÚBLICA. CASA CIVIL. Decreto de 16 de janeiro de 1997. Declara de interesse social, para fins de reforma agrária, o imóvel rural conhecido por "Fazenda Pinhal Ralo/Rio Bonito". Disponível em <http://www. planalto.gov.br/ccivil_03/DNN/Anterior\%20 a\%202000/1997/Dnn5085.htm> Acesso em: 07 Mar. 2011.

OLIVEIRA, V. M. R. de; CAMPISTA, V. do R. O silêncio: multiplicidade de sentidos. SINAIS - Revista Eletrônica - Ciências Sociais. Vitória: CCHN, UFES, Edição v.1, n.02, Outubro. 2007. p.107-120. Disponível em < http://www.indiciarismo.net/revista/ CMS/?download=02_08_Vania\%20Maria\%20 
e\%20Valesca_artigo.pdf> Acesso em 11 Mar. 2011.

ORLANDI, E. P. Análise do discurso: princípios e procedimentos. Campinas: Pontes, 1999.

. As formas do silêncio: no movimento dos sentidos. Campinas: Ed. da Unicamp, 2002. SANTOS, M. M. Sentidos e discursos dos jornais nordestinos sobre o MST. Estudos em Jornalismo e Mídia, Brasil, v. 4, n. 1, 2007. Disponível em <http://www.revistas. univerciencia.org/index.php/estudos/article/ view/5857/5328>. Acesso em: 28 Fev. 2011.

SERRA, E. Colonização, uso da terra e conflitos rurais no Paraná. Universidade Estadual de Maringá/Programa de Pós-Graduação em Geografia. Disponível em <http://egal2009. easyplanners.info/area06/6246_Serra_Elpidio. pdf> Acesso em: 08 Jan. 2010.

SOUZA, S. M. R. de; THOMAZ JÚNIOR, A. O discurso jornalístico e o movimento dos trabalhadores rurais sem-terra: o fato e a interpretação. (APÊNDICE - 7) p.109125. In. Thomaz Júnior, Antonio. Dinâmica geográfica do trabalho no século XXI: (Limites Explicativos, Autocrítica e Desafios Teóricos) / Antonio Thomaz Júnior. - São Paulo, 2009.

XAVIER, R. Representação social e ideologia: conceitos intercambiáveis? Psicologia \& Sociedade; 14 (2):18-47; jul./dez.2002 Disponível em <http://www.scielo.br/pdf/psoc/vi4n2/ v14n2a03.pdf> Acesso em: 12 Mar. 2011

Recebido para publicação em 28 de maio de 2013 Aceito para publicação em 4 de ago. de 2013 